\begin{tabular}{|c|c|c|}
\hline & Int.J.Curr.Microbiol.App.Sci (2021) 10(08): 396-401 & \\
\hline & $\begin{array}{l}\text { International Journal of Current Microfiology and Applied Sciences } \\
\text { ISSN: 2319-7706 Volume } \mathbf{1 0} \text { Number } \mathbf{0 8} \mathbf{( 2 0 2 1 )} \\
\text { Journal homepage: http://www.ijcmas.com }\end{array}$ & 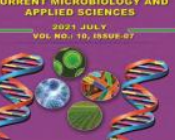 \\
\hline $\begin{array}{l}\text { EXCELLENT } \\
\text { PUBLISHERS }\end{array}$ & & wuw.ificmascom \\
\hline
\end{tabular}

Original Research Article

https://doi.org/10.20546/ijcmas.2021.1008.048

\title{
Evaluation of Pheromone Traps for Management of Fruit Fly (Bactrocera cucurbitae Coq.) Infesting Bitter Gourd - A Success Story
}

\author{
Deepak Jain $^{\text {* }}$, Hasmukh Kumar ${ }^{2}$, Bahadur Singh ${ }^{3}$, \\ Bhagwat Singh Chouhan ${ }^{1}$ and Prahlad Soni ${ }^{1}$ \\ ${ }^{1}$ KVK, Badgaon, Udaipur, Rajasthan-313 011, India \\ ${ }^{2}$ Department of Agricultural Engineering, KVK, Badgaon, Udaipur, Rajasthan-313 011, India \\ ${ }^{3}$ Department of Agronomy, KVK, Badgaon, Udaipur, Rajasthan-313 011, India \\ *Corresponding author
}

Keywords

Bitter gourd, fruit fly, pheromone

Article Info

Accepted:

20 July 2021

Available Online:

10 August 2021
A B S T R A C T

Fruit fly is a serious pest not only of cucurbits but other also of vegetable and fruit crops causing huge losses to farmers in Udaipur district. In spite of using hazardous pesticides, farmers are bound to bear about $30-70 \%$ yield loss every year due to the attack of fruit fly. Various front line demonstrations(FLD) of cue lure containing pheromone traps were laid out by KVK Badgaon, Udaipur at the fields of bitter gourd growers of the tribal dominated area during two consecutive years (2019-2020) to introduce and promote the ecofriendly management technology of fruit flies by installation of 20 traps/ha. The technology was found feasible, cheaper as well as easy to adopt at farmer's field. An average of 31.03 per cent increased yield was observed resulting $₹ 60675$ average increased income per hectare comparing with plots under farmer's practice where traps were not installed. It's very economic and ecofriendly method for the management of fruit flies.

\section{Introduction}

The cucurbits such as bitter gourd, cucumber, sponge gourd, ridge gourd, bottle gourd, snake gourd, ash gourd, pointed gourd and pumpkins are some of the major vegetables grown across Rajasthan and in India. Several biotic factors limit the production and productivity of cucurbits, of which cucurbit or melon fruit fly
(Bactrocera cucurbitae Coquillett) has been the most prominent pest over the last several decades in India, especially bitter gourd, Momordica charantia Linn. The melon fruit fly damage is the major limiting factor in obtaining good quality fruits and high yield (Srinivasan, 1959; Lall and Singh, 1969; Mote, 1975; Rabindranath and Pillai, 1986). It prefers young, green, and tender fruits for egg 
laying. The females lay the eggs 2 to $4 \mathrm{~mm}$ deep in the fruit pulp, and the maggots feed inside the developing fruits. At times, the eggs are also laid in the corolla of the flower, and the maggots feed on the flowers. A few maggots have also been observed to feed on the stems (Narayanan, 1953). Pupation occurs in the soil at 0.5 to $15 \mathrm{~cm}$ below the soil surface. The fruits attacked in early stages fail to develop properly, and drop or rot on the plant. The extent of losses by melon fruit fly in bitter gourd varies between 30 to $100 \%$ (Gupta and Verma, 1992; Dhillon et al., 2005). Its abundance increases when the temperatures fall below $32^{\circ} \mathrm{C}$, and the relative humidity ranges between 60 to $70 \%$. Considering previous facts and reports, it is apparent that $>50 \%$ of the cucurbits are either partially or totally damaged by fruit flies and are unsuitable for human consumption. Although, several management options, such as hydrolyzed protein spray, para-pheromone trap, spraying of ailanthus and cashew leaf extract, neem products, bagging of fruits, field sanitation, food baits, and spray of chemical insecticides (Pawar et al., 1991; Zaman, 1995; Neupane, 1999; Akhtaruzzaman et al., 2000; GCYD and Mandal, 2000; Satpathy and Rai, 2002; Jacob et al., 2007) have been in use for the management of cucurbit fruit fly, some of them either fail to control the pest and/or are uneconomic and hazardous to non-target organisms and the environment (Singh and Singh, 1998; Dhillon et al., 2005).

The management strategies employed for the control of fruit fly by farmers of the district is mostly concentrated on application of synthetic insecticides. Further, indiscriminate use of insecticides has led to problems of resistance to insecticides, pest resurgence, harmful pesticide residues and environmental pollution. Since, the maggots damage the fruits internally; it is difficult to control this pest with insecticides. Therefore, there is a need to explore alternative methods of control, and develop an integrated control strategy for effective management of this pest. The use of pheromone traps for the management of fruit fly has proved to be success in reducing the pest population for the past few years, apart from being eco-friendly. Cue-lure traps have been used for monitoring and mass trapping of the melon fruit flies in bitter gourd (Pawar $e t$ al., 1991; Permalloo et al., 1998; Seewooruthun et al., 1998). Pheromones are a class of semiochemicals that insects and other animals release to communicate with other individuals of the same species. The pheromone, 'cuelure' is used in cucurbits, which mimics the scent of female flies, attracts the male flies and traps them in large numbers resulting in check of population growth early in the season. The sex attractant cue-lure traps are more effective than the food attractant tephritlure traps for monitoring the B. cucurbitae in bitter gourd (Pawar et al., 1991).Cue-lure traps have been reported to attract $B$. cucurbitae males from mid-July to mid-November (Ramsamy et al., 1987; Zaman, 1995; Liu and Lin, 1993).

\section{Intervention of Krishi Vigyan Kendra, Udaipur, Rajasthan}

Tribal dominated village i.e. Kherad and Toorgarh are working under the jurisdiction of Krishi Vigyan Kendra, Bagdgaon, Udaipur, located in block Phalasiya, Udaipur, Rajasthan, where cultivation of cucurbits, particularly Bitter gourd, is grown over a large area. Proper and prolonged humid condition and sandy soil favours the cultivation of cucurbits. Thus, growing of bitter gourd has been proved as a best alternate to replace mono culture of tuber crops which have completely destroyed by rhizome rot disease in the area where majorities of farmers having small land holdings. KVK, Badgaon, Udaipur is also focusing to provide technical guidance to the bitter gourd farmers so that some area of tuber crop may be replaced by horticultural 
cash crops in the district. Fruit fly is a serious pest not only of cucurbits but other vegetable and fruit crops causing huge losses to farmers in Udaipur district. As per local farmer's feedback, in spite of using hazardous pesticides, they are bound to bear about $40-$ $70 \%$ yield loss every year due to the attack of fruit fly. Keeping above facts in view, several control tactics have been tested at National Institute of Plant Health Management (NIPHM) Hyderabad, National Center for Integrated Pest Management (NCIPM) New Delhi and at University level, through various trials conducted in collaboration with Krishi Vigyan Kendra and recommended the use of cue lure based pheromone traps as a best tool to enhance the productivity of cucurbitaceous crops in the district. Performance of traps to catch fruit flies have been particularly widely studied and documented, and vary between zones, predominant hosts and fly species (Agarwal and Kumar, 1999; Kumar et al., 1997, Verghese, 1998).

\section{Role of KVK, Udaipur in dissemination of technology}

Various front line demonstrations of cue lure containing pheromone traps were laid out by KVK Badgaon, Udaipur at the fields of bitter gourd growers during the year $2019 \& 2020$ to introduce and promote the ecofriendly management technology of fruit flies. The traps and lure (Cue lure) were procured from PCI, under the front line demonstrations programme (ICAR-NCIPM-TSP project) and distributed among 20 farmers as shown in figure 1 for installation @ 20 traps/ ha in bitter gourd crop during the first fortnight of June month. Pheromone trap installed prior to flower initiation and lure was replaced once after in one month till harvesting of fruits. The demonstrations continued for two consecutive years. Field visits were conducted prior to the programme and progressive farmers were selected and trained about the technology to ensure maximum impact of the programme. During the demonstration programme, scientists frequently visited farmers field to ensure the proper installation of traps in field, cleaning of traps at right interval, recharging of lures and not to spray any pesticide for the management of fruit flies (fig-1). Scientists of KVK popularized the demonstrated technology through other extension activities i.e. Off/On campus training programmes, stalls at kisan mela, kisan gosthies, exposure visits and by conducting special campaigns for popularization of Eco friendly traps in the area so that maximum number of cucurbits growers of the area may be benefitted.

\section{Results of FLD Programme}

The technology was found feasible, cheaper as well as easy to adopt at farmer's field. Performance of "cue lure" traps was well appreciated by farmer in terms of increased yield. Farmers were also satisfied with the proper shape and size of the fruits due to management of fruit flies resulting better market demand of their produce. Scientists analyzed the economics of using pheromone traps for the ecofriendly management of fruit fly in bitter gourd on the basis of data obtained from two consecutive years (Table 1).An average of 31.03 per cent increased yield was observed resulting (₹)60675 average increased income per hectare comparing with plots under farmer's practice where traps were not installed. Farmers were also appreciating the technology due to relief from labour arrangement for unnecessary spraying. Results were eye opener for the farmers. Now, the cucurbits growers of the area are well aware with the technology and directly purchasing and installing the traps well in advance for the management of fruit flies not only in bitter gourd but also in other cucurbitaceous crops i.e. cucumber, bottle gourd and pointed gourds grown in area as shown in figure 1. 
Table.1 Economic so fusing Cuelure traps for the management of fruit fly in Bitter gourd.

\begin{tabular}{|c|c|c|c|c|c|c|c|c|c|}
\hline \multicolumn{4}{|c|}{ EconomicsofDemonstration(/ha) } & \multicolumn{4}{c|}{ EconomicsofFarmerPractice(Rs/ha) } \\
\hline $\begin{array}{c}\text { Yield(q/ } \\
\text { ha) }\end{array}$ & $\begin{array}{c}\text { GrossC } \\
\text { ost } \\
(₹)\end{array}$ & $\begin{array}{c}\text { GrossR } \\
\text { eturn } \\
(₹)\end{array}$ & $\begin{array}{c}\text { Net } \\
\text { Return } \\
(₹)\end{array}$ & BCR & $\begin{array}{c}\text { Yield(q/ } \\
\text { ha) }\end{array}$ & $\begin{array}{c}\text { Gross } \\
\text { Cost } \\
(₹)\end{array}$ & $\begin{array}{c}\text { Gross } \\
\text { Return } \\
(₹)\end{array}$ & $\begin{array}{c}\text { Net } \\
\text { Return } \\
(₹)\end{array}$ & BCR \\
\hline 102.47 & 48000 & 256175 & 208175 & $1: 5.33$ & 78.20 & 45000 & 195500 & 150500 & $1: 4.34$ \\
\hline
\end{tabular}

Fig.1

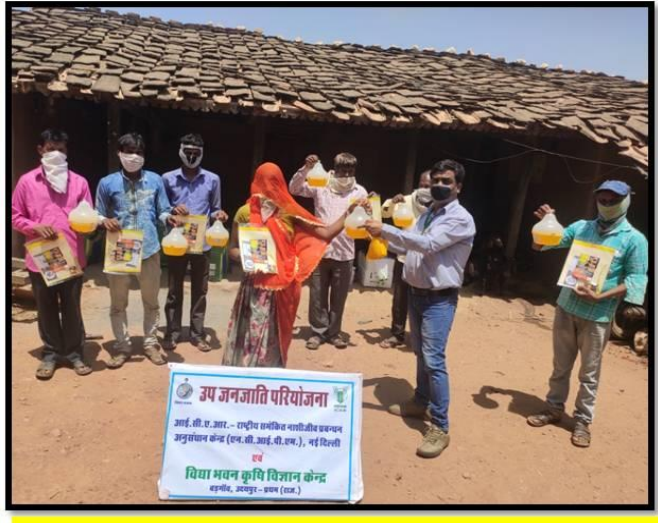

Distribution of pheromone trap with lure

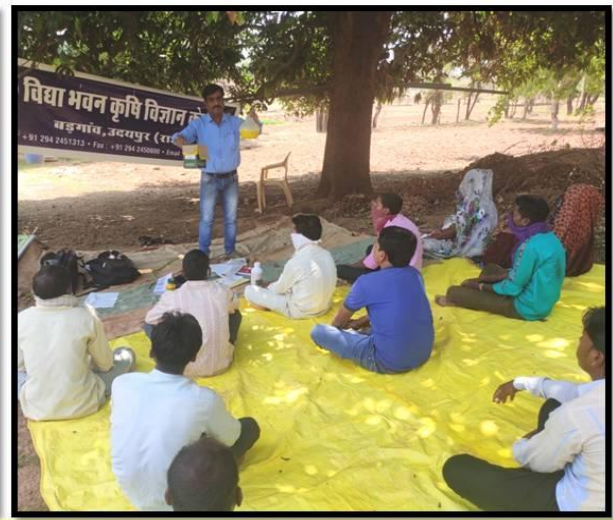

Training to farmers

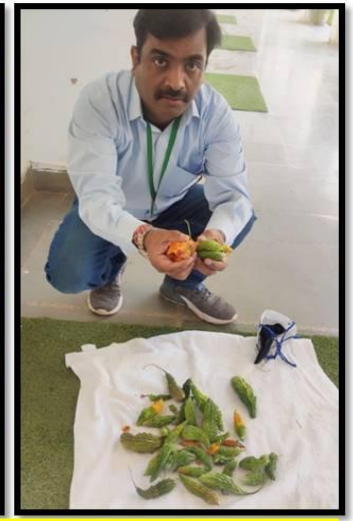

fruit fly infected fruits

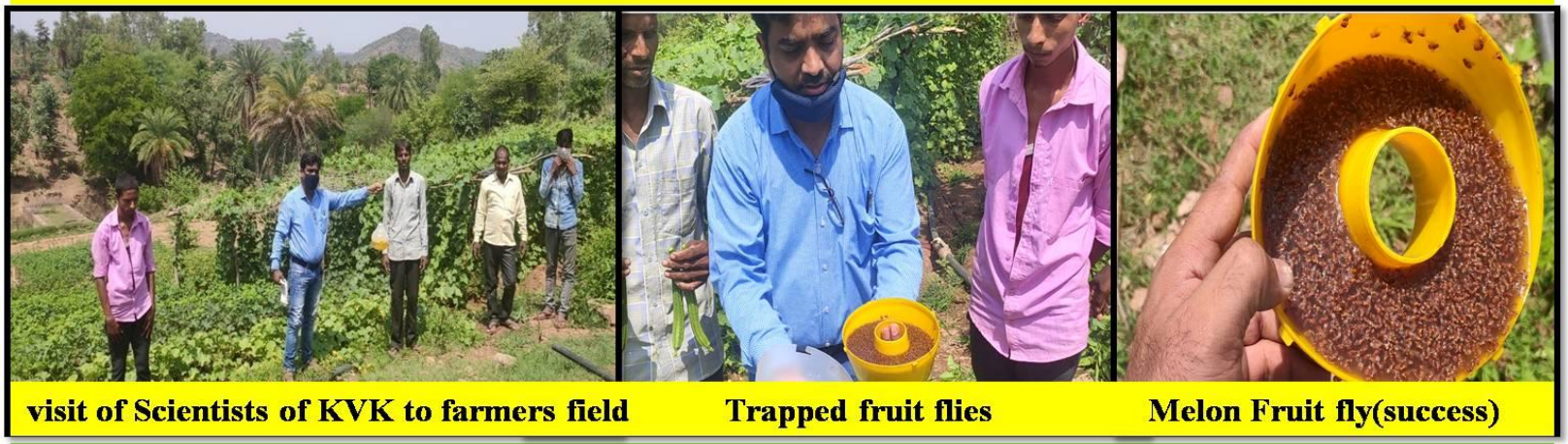

Fig-1..Assessment of pheromone trap for eco friendly management of fruit fly under FLD in bitter gourd at Kherad village,Udaipur Rajasthan

Scientists of Krishi Vigyan Kendra, Udaipur are now planning to move in other vegetable belts of cucurbits in the district to further disseminate the technology

Future Aspect

Since the technique employed is male annihilation technique, the population of the pest will automatically decline in future. This will be highly beneficial for the farming community which were otherwise employing blanket application of insecticides and getting poor yield due to heavy fruit fly attack in Udaipur district. Further, the farmers are now being trained to lower the cost of the technology by making homemade traps. Used mineral water or soft drinks bottles may be utilized with four windows of $1.5 \mathrm{~cm}$ diameter. The wooden blocks should be placed almost at the same level of the windows. The use less plastic water/soft drinks bottles are also performing well and lowering the cost of 
technology. Farmers may purchase only lures to be recharged in the home made traps. Scientists of the centre are now popularizing the home made traps among cucurbits growers for maximum adoption of the technology at lowest cost, shown in figure 1 .

\section{Impact}

This technology helps to suppress further population build-up of insect with almost no probability of insecticide residue in and or/on the fruits.

This technology decreases fruit damage about60 -70\% in cucurbits. Overall cost of pesticide application is decreased more than 10 times.

Benefit is in terms of pesticide free cucurbits, safety to human health and improving quality of environment

\section{References}

Agarwal, M. L. and Kumar, P. 1999. Effect of weather parameters on population dynamics of peach fruit fly, Bactrocera zonata (Saunders). Entomo., 24: 81-84.

Akhtaruzzaman, M., Alam, M. Z. and AliSardar, M. M. 2000. Efficiency of different bait sprays for suppressing fruit fly on cucumber. Bull. Inst. Trop. Agric. (Kyushu University). 23: 15-26.

Dhillon, M. K., Naresh, J. S., Singh, R. and Sharma, N.K. 2005. Evaluation of bitter gourd (Momordica charantia L.) genotypes for resistance to melon fruit fly, Bactrocera cucurbitae. Indian J. Pl. Prot. 33(1): 55-59.

GCYD and Mandal, C. K. 2000. Integrated management of fruit fly (Bactrocera cucurbitae) on bitter gourd (Momordicha charantia L.) during the summer of (1998/99). IAAS Res. Rep.
(1995-2000): 171-175.

Gupta, D. and Verma, A. K. 1992. Population fluctuations of the maggots of fruit flies Dacus cucurbitae Coquillett and D. tau (Walker) infesting cucurbitaceous crops. Adv. Pl. Sci. 5: 518-523.

Jacob, J., Leela, N. K., Sreekumar, K. M., Anesh, R.Y. and Heema, M. 2007. Phyto- toxicity of leaf extracts of multipurpose tree against insect pests in bitter gourd (Momordica charantia) and brinjal (Solanum melongena). Allelopathy J. 20(2): 1-2.

Kumar, S., Patel, C. B. and Bhatt, R. I. 1997. Studies on seasonal cyclicity of Bactrocera correctus Bezzi in mango and sapota orchards using methyl eugenol trap. Gujarat Agric. Univ. Res. J., 22:, 68-74.

Lall, B. S. and Singh, B. N. 1969. Studies on the biology and control of melon fly, Dacus cucurbitae (Coq.) (Diptera: Tephritidae). Labdev Journal of Science and Technology 7B: 148-153.

Liu, Y. C. and Lin, J. S. 1993. The response of melon fly, Dacus cucurbitae Coquillett to the attraction of $10 \% \mathrm{MC}$. Plant Protection Bulletin Taipei 35: 79-88.

Mote, U. N. 1975. Control of fruit fly (Dacus cucurbitae) on bittergourd and cucumber. Pesticides 9: 3637.Mumford JD. 2004. Economic analysis of area-wide fruit fly.

Narayanan, E. S. 1953. Seasonal pests of crops. Indian Farming 3(4): 8-11 \& 2931.

Neupane, F. P. 1999. Field evaluation of botanicals for the management of cruciferous vegetable insect pests. Nepal J. Sci. Tech. 2: 95-100.

Pawar, D. B., Mote, U. N. and Lawande, K. E. 1991. Monitoring of fruit fly population in bitter gourd crop with the help of lure trap. Journal of Research, Maharashtra

Agricultural 
Universities16: 281.

Permalloo, S., Seewooruthun, S. I., Joomaye, A., Soonnoo, A. R. Gungah, B., Unmole, L, and Boodram, R.1998. An area wide control of fruit flies in Mauritius. In: Lalouette JA, Bachraz D Y, Sukurdeep N, Seebaluck B D editors. Proceedings of the Second Annual Meeting of Agricultural Scientists, 12-13August 1997, pp. 203210. Food and Research Council, Reduit, Mauritius. Prokopy R J, Miller $\mathrm{N} \mathrm{W}$, Pinero.

Rabindranath, K., and Pillai, K. S. 1986. Control of fruit fly of bittergourd using synthetic pyrethroids. Entomon 11: 269-272.

Ramsamy, M. P., Rawanansham, T.and Joomaye, A. 1987. Studies on the control of Dacus cucurbitae Coquillett and Dacusd'emmerezi Bezzi (Diptera: Tephritidae) by maleannihilation. Revue Agricole et Sucriere de ltle Mauriee 66:1-3.

Satpathy, S. and Rai, S. 2002. Luring ability of indigenous food baits for fruit fly $B$. cucurbitae (Coq.). Indian J. Ent. Res. 26(3): 249-252.

Seewooruthun, S. I., Sookar, P., Permalloo, S.,
Joomaye, A., Alleck, M., Gungah, B. and Soonnoo, A. R. 1998. An attempt to the eradicationof the Oriental fruit fly, Bactrocera dorsalis (Hendel) from Mauritius. In: Lalouette J A, Bachraz D Y, Sukurdeep N, Seebaluck B D editors. Proceedings of the Second Annual Meeting of Agricultural Scientists, 12-13 August 1997, pp.181187. Food and Research Council, Reduit, Mauritius.

Singh, S. and Singh, R. P. 1998. Neem (Azadirachta indica) seed kernel extracts and Azadirachtin as oviposition deterrents against the melon fly (B. cucurbitae) and oriental fruit fly (B. dorsalis). Phytoparasitica. 26(3): 1-7.

Srinivasan, P. M. 1959. Guard your bitter gourd against the fruit fly. Indian Farming 9: 8.

Verghese, A. 1998. Methyl eugenol attracts female mango fruit fly, Bactrocera dorsalis Hendel. Insect Envir., 4 : 101.

Zaman, M. 1995. Assessment of the male population of the fruit flies through kairomone baited traps and the association of the abundance levels with the environmental factors.

\section{How to cite this article:}

Deepak Jain, Hasmukh Kumar, Bahadur Singh, Bhagwat Singh Chouhan and Prahlad Soni. 2021. Evaluation of Pheromone Traps for Management of Fruit Fly (Bactrocera cucurbitae Coq.) Infesting Bitter Gourd - A Success Story. Int.J.Curr.Microbiol.App.Sci. 10(08): 396-401. doi: https://doi.org/10.20546/ijcmas.2021.1008.048 